\title{
БІОБЕЗПЕКА ТА ОХОРОНА ПРАЦІ
}

\author{
Ціник М.І., студентка \\ marytsinyk@gmail.com \\ Бесараб О. Б., к.т.н. \\ besarab@lll.kpi.ua \\ Мотроненко В. В., д-р філос. \\ motronenkovalya@gmail.com \\ Національний технічний університет України \\ "Київський політехнічний інститут імені Ігоря Сікорського" \\ м. Київ, Україна
}

\begin{abstract}
Реферат - Питання біологічної безпеки та біозахисту мають важливе значення для репутації та відповідальності кожної наукової установи, будь то дослідницька, наукова чи виробнича. Кожен ризик-яким би малим він не був - повинен бути врахований, оиінений та належним чином пом'якшений. У иій статті ми проводимо огляд основних патогенних біологічних об'єктів, надаємо статистику співвідношення виявлених випадків захворювання та смертності серед основних лабораторно-набутих інфекиіі (Laboratory-acquired infections) (LAI) та співвідношення виявлених випадків захворювання та смертності серед основних умовнопатогенних біологічних агентів. Розглядаємо підбір заходів, щъо керують впровадженням біобезпеки та біозахисту в обмежених середовищах, $і$ те, як вони застосовуються в Україні, серед чого визначаємо, які заходи проводять у лабораторії кожного рівня біологічної безпеки (Biological safety levels) (BSL). Коротко характеризуємо особливості контролю за мікробіологічним забрудненням біотехнологічної та фармацевтичної продукиії. В результаті проведеного аналізу можемо зробити висновок, що хоча біобезпека та біозахист направлені на здійснення різних иілей, вони часто вирімуються разом, особливо в умовах обмеженого використання, призначені для забезпечення безпеки прачівників лабораторій, включають використання різних первинних та вторинних бар'єрів, багато з яких зумовлені появою нових технологій у галузі матеріалознавства та техніки.

Ключові слова: біозахист, біобезпека, охорона праці, група ризику, LAI, BSL
\end{abstract}

\section{I. ВСТУП}

Біобезпека є основною проблемою в усіх біомедичних та медичних установах у всьому світі. Потреба в запровадженні норм та заходів щодо біобезпеки та біозахисту зростає через широке використання мікробних збудників [1]. "Біобезпека" має кілька визначень залежно від дисципліни (ветеринарна, харчова, медична, екологічна чи космічна), або навіть країни, в якій вона використовується. Всесвітня Організація Охорони Здоров'я (ВОО3) надає таке визначення терміну "біобезпека" “описує принципи зберігання, технології та практики, що застосовуються для запобігання ненавмисному впливу патогенних мікроорганізмів та токсинів або їх випадкового викиду" [2].

Також цей термін іноді використовується як взаємозамінний термін із "біозахистом", хоча сам по собі він має багато різних визначень. Згідно ВООЗ біозахист описує захист, контроль та відповідальність за цінні агенти та токсини біологічних матеріалів у лабораторіях з метою запобігання їх втраті, крадіжці, неправильному використанню, відволіканню, несанкціонованому доступу чи навмисному несанкціонованому вивільненню [2]. Внаслідок такої різноманітності “біобезпека" та "біозахист" часто використовуються без узгодженого визначення або сфери застосування. Національна дослідницька рада чітко резюмує різницю: біобезпека - це "захист людей від помилок"; біозахист - це захист “помилок” від людей [3].

\section{META}

Не пропонуючи конкретного підходу, огляд має на меті підкреслити, що для забезпечення безпеки при роботі з біологічним матеріалом були введені різні системи, починаючи від добровільної практики та закінчуючи законодавчими вимогами.

\section{III. ПОТЕНЦІЙНО НЕБЕЗПЕЧНІ БІОЛОГІЧНІ ОБ'СКТИ}

У біотехнології існує багато біологічних об'єктів, таких як бактерії, віруси, грибки та паразити. Питання біобезпеки та біозахисту в біомедичних лабораторіях зосереджене на нових вакцинах, діагностичних інструментах або терапевтичних засобах, деякі 3 яких виготовляються за допомогою генної інженерії [4]. В даний час головне занепокоєння щодо біобезпеки пов'язано з появою нових хвороб або повторним виникненням старих. Останнім часом встановлено, що інфекційні захворювання $\epsilon$ найбільш частими серед професійних захворювань [5]. 
На основі основних характеристик біологічних збудників різноманітних захворювань, шляху передачі хвороби та небезпеки для лабораторного персоналу, працівників та громади, ВОО3 розробила систему класифікації мікроорганізмів на чотири різні групи, яка наведена в таблиці 1.

Таблиця 1. Класифікація мікроорганізмів згідно груп ризику[2]

\begin{tabular}{|c|c|c|c|}
\hline $\begin{array}{c}\text { Група } \\
\text { ризиків }\end{array}$ & Індивідуальний ризик & Ризик спільноти & Приклади \\
\hline 1 & Низький & Низький & $\begin{array}{c}\text { Escherichia coli K12, Saccharomyces } \\
\text { cerevisiae, Bacillus subtilis }\end{array}$ \\
\hline 2 & Помірний & Низький & Streptococcus, Bipyc npocmozo геpnecy \\
\hline 3 & Високий & Низький / помірний & Yersinia pestis, BIJ, Kopoнaвipycu \\
\hline 4 & Високий & Високий & Ebola virus, Marburg virus, Lassa virus \\
\hline
\end{tabular}

Перша група ризику включає мікроорганізми, що навряд можуть спричинити захворювання людей чи тварин. До другої групи включають патогени, які можуть спричинити захворювання людей чи тварин, але навряд можуть становити серйозну небезпеку для працівників лабораторій, громади, худоби чи навколишнього середовища. Лабораторний вплив може спричинити серйозну інфекцію, але доступні ефективні методи лікування та профілактики, i ризик поширення інфекції обмежений. Найбільшу небезпеку в собі несе робота з організмами третьої та четвертої групи ризику. Третя група включає патогени, що зазвичай викликають серйозні захворювання людини або тварин, але зазвичай не поширюються від однієї зараженої особини до іншої.

Для них доступні ефективні лікувальні та профілактичні заходи. Четверта група виділяє патогени, який зазвичай викликають серйозні захворювання людей або тварин і можуть легко передаватися від однієї особи до іншої, прямо чи опосередковано. Для них характерне ефективне лікування, однак профілактичні заходи зазвичай відсутні $[1,5]$.

Лабораторно-набуті інфекції (Laboratoryacquired infections) (LAI) представляють серйозну біологічну небезпеку не лише для навколишнього середовища, а й для громадського здоров'я, зокрема працівників лабораторій, які працюють 3 різноманітними об'єктами. [6] Термін LAI означає всі інфекції, отримані внаслідок лабораторних робіт або пов'язаних з лабораторією заходів, з початком інфекцій або без них, і загалом наслідки від професійної діяльності з інфекційними агентами $[7]$.

LAI, обумовлені широким розмаїттям бактерій, вірусів, грибків та паразитів, на даний момент широко описані в літературі. Найбільший огляд інфекцій був проведений у 1976 р. Пайком, який виявив, що 4079 LAI були спричинені 159 біологічними об'єктами, хоча лише десять об'єктів викликали інфекції, що становить 50\% від загальної кількості випадків [6]. Основні хвороби представлені в таблиці 2.

Таблиця 2. Співвідношення виявлених випадків захворювання та смертності серед основних LAI [8]

\begin{tabular}{|c|c|c|}
\hline Хвороба & $\begin{array}{c}\text { Число випадків на 100 000 } \\
\text { лабораторних технологів }\end{array}$ & $\begin{array}{c}\text { Число смертей на 100 000 лабораторних } \\
\text { технологів }\end{array}$ \\
\hline Brucellosis & 426 & 5 \\
\hline Qfever & 280 & 1 \\
\hline Hepatitis & 268 & 3 \\
\hline Typhoidfever & 258 & 20 \\
\hline Tularemia & 225 & 2 \\
\hline Tuberculosis & 194 & 4 \\
\hline Psittacosis & 116 & 10 \\
\hline
\end{tabular}

Уже під час опитування керівників клінічних лабораторій 2002-2004 pp., які беруть участь у Інтернет-форумі ClinMicroNet, спонсорованому Американським товариством Таблиця 3. Співвідношення виявлених випадків захворювання та смертності серед основних умовно-патогенних біологічних агентів $[9,10]$ мікробіології, 33\% лабораторій повідомили про наявність принаймні 1 лабораторноасоційованої інфекції. Основні організмизбудники представлені в таблиці 3.

\begin{tabular}{|c|c|c|}
\hline Мікроорганізм & $\begin{array}{c}\text { Число випадків на } 100000 \text { лабораторних } \\
\text { технологів }\end{array}$ & $\begin{array}{c}\text { Відносний ризик } \\
\text { інфікування }\end{array}$ \\
\hline
\end{tabular}




\begin{tabular}{|l|c|c|}
\hline Mycobacterium tuberculosis & 15 & 1 \\
\hline Brucella species & 7 & 80,125 \\
\hline Salmonella species & 6 & 0,08 \\
\hline Neisseria meningitidis & 4 & 40,8 \\
\hline Escherichia coli O157:H7 & 2 & 8,6 \\
\hline
\end{tabular}

Трьома найпоширенішими лабораторними інфекціями виявився туберкульоз, бруцельоз та сальмонельоз. Найвища кількість випадків зараження була пов'язана з видами Brucella (641 випадок на 100000 лабораторних технологів порівняно з 0,08 випадками на 100000 осіб у загальній популяціï) та Neisseria meningitidis $(25,3$ випадків на $100 \quad 000$ лабораторних технологів проти 0,62 випадків на 100000 осіб у загальній сукупності) [11].

Вірусні агенти, що передаються через кров та тілесні рідини, також спричиняють більшість лабораторних інфекцій у діагностичних лабораторіях та серед медичних працівників. Вірус гепатиту В (ВГВ) $\epsilon$ найпоширенішою причиною зараження в лабораторних умовах [12]. Частота зараження ВГВ серед усіх медичних працівників США, за оцінками, становить 3,5-4,6 зараження на 1000 працівників, що в 2-4 рази перевищує рівень серед населення [9].

Найбільше занепокоєння викликає зараження вірусом імунодефіциту людини (ВІЛ), пов'язане з впливом зараженої крові або рідин організму. За оцінками, ризик передачі ВІЛ після черезшкірного впливу ВІЛінфікованої крові становить 30,3\%, а 90,09\% після впливу на слизову оболонку [13].

\section{IV. ОРГАНІЗАЦІЙНІ ЗАХОДИ ТА ТЕХНІЧНІ ЗАСОБИ ЩОДО КОНТРОЛЮ ПОТЕНЦІЙНИХ РИЗИКІВ}

Для безпечного проведення досліджень 3 потенційно небезпечними мікроорганізмами дослідник повинен [14]:

- визначити

компоненти (ідентифікація небезпеки);

- оцінити додаткові ризики, пов'язані 3 маніпулюванням матеріалами під час експериментів (оцінка ризику);

- встановити

засоби, обладнання та практику, необхідні для захисту працівників від виявленого ризику (управління ризиками).

Існують принципи, що лежать в основі проектування лабораторій. Вводять дві концепції в проектуванні лабораторій. Перший це концепція первинних та вторинних бар'єрів, a другий забезпечує розробникам логічний розподіл основних функціональних зон у лабораторній будівлі [15].

Первинні заходи стримування мінімізують професійний вплив працівників лабораторій. На додаток до суворого дотримання належної мікробіологічної практики, основний бар'єр утримання включає фізичне відокремлення біологічно небезпечного агента від працівника лабораторії за допомогою закритих посудин, засобів індивідуального захисту (наприклад, рукавичок або костюмів для всього тіла) та додаткового обладнання (наприклад, BSC, закриті контейнери для центрифуг або допоміжні засоби для піпетування) [13].

Вторинні бар'єри забезпечують додаткове утримання, слугуючи головним чином для захисту інших працівників установи та запобігання виходу інфекційних агентів із лабораторії, якщо і відбувається первинна відмова первинних бар'єрів. Вони забезпечують поділ між потенційно забрудненими територіями в будівлі та зовнішнім середовищем [14]. Ці заходи можуть включати спеціальні процедури (наприклад, перевірені методи дезактивації, навчання персоналу, суворо контрольовані зони доступу, заблоковані двері тощо) та спеціальні технічні та конструктивні особливості (наприклад, обладнання для дезактивації, душові кабіни, автоклави, спеціальна система обробки повітря 3 фільтри тощо) [8].

Рекомендації ВОО3 встановлюють чотири рівні біобезпеки (Biosafety level, BSL). BSL - це низка заходів безпеки, які направлені на зменшення ризику впливу потенційно інфекційних біологічно-небезпечних агентів на лабораторний персонал [2].

Кожен рівень біобезпеки включає мікробіологічні практики, обладнання та засоби захисту для убезпечення працівників лабораторій, громадськості та навколишнього середовища від впливу інфекційних біологічних небезпек, які використовуються в лабораторії. Ці засоби контролю утримуються на попередньому рівні безпеки, як піраміда, із збільшенням рівня ризику. Рівні біобезпеки 
визначають тип робочих практик, які дозволяється виконувати в лабораторіях, i відіграють величезну роль у проектуванні об’єкта [15]. Загальні заходи, що прийнятні до кожного з рівнів, зображені в таблиці 4.

\section{V. НОРМАТИВНО-ПРАВОВА БАЗА УКРАЇНИ У СФЕРІ ОХОРОНИ ПРАЦІ.}

Для усунення можливих ризиків при роботі 3 біологічними об'єктами в установах різного рівня захисту необхідне дотримання правил поводження 3 біологічними об'єктами. Настанова ВОO3 із біобезпеки рекомендує для кожної країни розробляти власні стандарти безпеки на основі Настанови, однак в Україні ця робота знаходиться на стадії розробки.

Нормативно-правові документи, що регулюють сферу охорони праці при роботі 3 біологічними об'єктами, в Україні представлені наступними документами:

\section{Закон України “Про забезпечення} санітарного та епідемічного благополуччя населення" [16].

Цей Закон регулює суспільні відносини, які виникають у сфері забезпечення санітарного та епідемічного благополуччя і визначає відповідні права i обов'язки державних органів, підприємств, установ, організацій та громадян.

Згідно Закону державне регулювання у сфері забезпечення санітарного та епідемічного благополуччя населення передбачає:

- гігієнічну регламентацію i державну реєстрацію небезпечних факторів;

$$
\text { - державну }
$$$$
\text { санітарно- }
$$

епідеміологічну експертизу.

Закон визначає також вимоги щодо:

- ліцензування видів діяльності, пов'язаних 3 потенційною небезпекою для здоров'я людей;

- безпеки для здоров'я i життя населення у державних стандартах та інших нормативно-технічних документах;

- проектування, будівництва, розробки, виготовлення і використання нових засобів виробництва та технологій.

Закон визначає також порядок організації державної санітарно-епідеміологічної служби в Україні та здійснення державного санітарноепідеміологічного нагляду в Україні.

Таблиця 4. Загальні заходи, що застосовуються у лабораторії відповідного рівня BSL $[2,5,14]$

\begin{tabular}{|c|c|c|c|c|}
\hline $\begin{array}{c}\text { Рівень } \\
\text { біобезпеки }\end{array}$ & $\begin{array}{c}\text { Характеристики } \\
\text { агента } \\
\end{array}$ & Практики & $\begin{array}{c}\text { Обладнання безпеки } \\
\text { (первинні бар'сри) }\end{array}$ & $\begin{array}{c}\text { Послуги (вторинні } \\
\text { бар'єри) }\end{array}$ \\
\hline BSL - 1 & $\begin{array}{l}\text { Відомий, що } \\
\text { постійно викликає } \\
\text { захворювання у } \\
\text { здорових дорослих }\end{array}$ & $\begin{array}{l}\text { Стандартні } \\
\text { мікробіологічні } \\
\text { практики }\end{array}$ & Не потрібно & $\begin{array}{l}\text { Відкрита настільна } \\
\text { мийка }\end{array}$ \\
\hline BSL - 2 & $\begin{array}{l}\text { Пов’язаний із } \\
\text { захворюваннями } \\
\text { людини, небезпека } \\
\text { через шкірну } \\
\text { травму, } \\
\text { потрапляння } \\
\text { всередину, } \\
\text { опромінення } \\
\text { слизової оболонки }\end{array}$ & $\begin{array}{l}\text { Стандартні } \\
\text { мікробіологічні } \\
\text { практики } \\
\text { Обмежений доступ } \\
\text { Попереджувальні знаки } \\
\text { щодо біологічної } \\
\text { небезпеки } \\
\text { Заходи безпеки } \\
\text { “Sharps” } \\
\text { Посібник з біобезпеки, } \\
\text { що визначає необхідні } \\
\text { правила дезактивації } \\
\text { відходів або медичного } \\
\text { нагляду }\end{array}$ & $\begin{array}{l}\text { Шафи з біобезпеки класу } \\
\text { I або II (збалансована } \\
\text { система показників } \\
\text { (balanced scorecard) } \\
\text { (BSC) або інші пристрої } \\
\text { фізичного утримання, що } \\
\text { використовуються для } \\
\text { всіх маніпуляцій із } \\
\text { агентами, що } \\
\text { викликають бризки або } \\
\text { аерозолі інфекційних } \\
\text { матеріалів } \\
\text { Лабораторні пальто та } \\
\text { рукавички } \\
\text { Захист обличчя за } \\
\text { потреби }\end{array}$ & $\begin{array}{l}\text { Відкрита автоклавна } \\
\text { раковина }\end{array}$ \\
\hline
\end{tabular}

Продовження Таблиці 4

\begin{tabular}{|c|l|l|l|c|}
\hline $\begin{array}{c}\text { Рівень } \\
\text { біобезпеки }\end{array}$ & $\begin{array}{c}\text { Характеристики } \\
\text { агента }\end{array}$ & \multicolumn{1}{|l}{ Практики } & $\begin{array}{c}\text { Обладнання безпеки } \\
\text { (первинні бар'єри) }\end{array}$ & $\begin{array}{c}\text { Послуги (вторинні } \\
\text { бар'єри) }\end{array}$ \\
\hline BSL - 3 & $\begin{array}{l}\text { Корінні або } \\
\text { екзотичні агенти, }\end{array}$ & Всі практики BSL - 2 & $\begin{array}{l}\text { BSC класу I або II або } \\
\text { інші фізичні утримуючі }\end{array}$ & $\begin{array}{l}\text { Відкрита раковина на } \\
\text { стільниці }\end{array}$ \\
\hline
\end{tabular}




\begin{tabular}{|c|c|c|c|c|}
\hline & $\begin{array}{l}\text { які можуть } \\
\text { передавати } \\
\text { аерозолі; } \\
\text { захворювання може } \\
\text { мати серйозні або } \\
\text { летальні наслідки }\end{array}$ & $\begin{array}{l}\text { Контрольований } \\
\text { доступ } \\
\text { Дезактивація всіх } \\
\text { відходів } \\
\text { Дезактивація } \\
\text { лабораторного одягу } \\
\text { перед відмиванням } \\
\text { Базова сироватка }\end{array}$ & $\begin{array}{l}\text { пристрої, що } \\
\text { використовуються для } \\
\text { всіх відкритих } \\
\text { маніпуляцій з агентами } \\
\text { Захисний лабораторний } \\
\text { одяг та рукавички } \\
\text { Захист органів дихання } \\
\text { за необхідності }\end{array}$ & $\begin{array}{l}\text { Автоклав } \\
\text { Фізичне } \\
\text { відокремлення від } \\
\text { коридорів доступу } \\
\text { Самозамикання, } \\
\text { подвійний дверний } \\
\text { доступ Вихлопне } \\
\text { повітря не } \\
\text { рециркулюється } \\
\text { Негативний потік } \\
\text { повітря в } \\
\text { лабораторію }\end{array}$ \\
\hline BSL - 4 & $\begin{array}{l}\text { Небезпечні / } \\
\text { екзотичні агенти, } \\
\text { які становлять } \\
\text { високий ризик } \\
\text { захворювання, що } \\
\text { загрожує } \\
\text { життю; аерозольні } \\
\text { лабораторні } \\
\text { інфекції; або } \\
\text { пов’ язані з ними } \\
\text { агенти з невідомим } \\
\text { ризиком передачі }\end{array}$ & $\begin{array}{l}\text { Всі BSL - } 3 \\
\text { практикують зміну } \\
\text { одягу перед входом в } \\
\text { душ при виході } \\
\text { Весь матеріал } \\
\text { знезаражений при } \\
\text { виході з приміщення }\end{array}$ & $\begin{array}{l}\text { Усі процедури, що } \\
\text { проводяться в BSC класу } \\
\text { III або BSC класу I або II } \\
\text { у поєднанні з костюмом } \\
\text { персоналу з позитивним } \\
\text { тиском у всьому тілі }\end{array}$ & $\begin{array}{l}\text { BSL - } 3 \text { plus: Окрема } \\
\text { будівля чи ізольована } \\
\text { зона } \\
\text { Виділені системи } \\
\text { подачі та витяжки, } \\
\text { вакууму та } \\
\text { дезактивації }\end{array}$ \\
\hline
\end{tabular}

Закон Украӥни “Про державну систему біобезпеки при створенні, випробуванні, транспортуванні та використанні генетично модирікованих організмів" [17].

Цей Закон регулює відносини між органами виконавчої влади, виробниками, продавцями (постачальниками), розробниками, дослідниками, науковцями та споживачами генетично модифікованих організмів та продукції, виробленої за технологіями, що передбачають їх розробку, створення, випробування, дослідження, транспортування, імпорт, експорт, розміщення на ринку, вивільнення у навколишнє середовище та використання в Україні із забезпеченням біологічної і генетичної безпеки.

Держсавні санітарні норми $і$ правила “Організація роботи лабораторій при дослідженні матеріалу, ще містить біологічні патогенні агенти I-IV груп патогенності молекулярно-генетичними методами" [18].

Правила встановлюють вимоги до приміщень лабораторій і порядку організації і проведення в них робіт 3 патогенними біологічними агентами I-IV груп патогенності або матеріалом, підозрюваним на їх вміст, 3 використанням молекулярно-генетичних методів, заснованих на полімеразній ланцюговій реакції. Правила регламентують виконання досліджень методом ПЛР із застосуванням обладнання, реагентів, тест-систем, дозволених до використання на території України. Правила поширюються на лабораторії, відділи, відділення мікробіологічного профілю установ охорони здоров'я, закладів науки та освіти, спеціалізовані лабораторії незалежно від їх підпорядкування та форм власності, що проводять молекулярно-генетичні дослідження 3 патогенними біологічними агентами I-IV груп патогенності або матеріалом, підозрюваним на ï вміст, дослідження 3 контролю об'єктів довкілля, харчових продуктів та продовольчої сировини за показниками безпеки, а також на наявність генетично-модифікованих джерел.

\section{VI. ОСОБЛИВОСТІ КОНТРОЛЮ ЗА МІКРОБІОЛОГІЧНИМ ЗАБРУ ДНЕННЯМ}

У фармацевтичній галузі основним документом $є$ Настанову СТ-Н МО3У 424.0:2020 "Лікарські засоби. Належна виробнича практика”. ВОО3 та Міжнародною федерацією фармацевтів було рекомендовано ввести мікробіологічний контроль лікарських препаратів у національні фармакопеї. Згідно із запропонованою схемою аналізу, в лікарських препаратах слід визначати загальну кількість життєздатних бактерій і грибів та виявляти деякі види патогенних мікроорганізмів, наявність яких у ліках неприпустима. Дослідження проводять в асептичних умовах з використанням наведених у Державній фармакопеї України 2 методів (методу глибинного або поверхневого висівання на чашки Петрі або метод мембранної фільтрації) i живильних середовищ для контролю всіх видів лікарських препаратів, а 
також сировини, яка використовується при їх виробництві [19].

Для забезпечення якості лікарських препаратів, у т.ч. мікробіологічної чистоти, необхідне виконання правил належної виробничої практики (Good Manufacturing Practice) GMP, які передбачають систему заходів щодо профілактики можливих відхилень у процесі виробництва. Ці правила спрямовані на виявлення та усунення тих несприятливих виробничих умов, які можуть призвести до виготовлення неякісної продукції. Згідно 3 вимогами GMP BOO3 чисті приміщення для виробництва стерильної продукції класифікує у відповідності вимог до характеристик на класи чистоти A, B, C і D [20]. Стерильні лікарські засоби (ЛЗ) необхідно виготовляти в чистих зонах. Доступ персоналу і/чи вихідної сировини, матеріалів, напівпродуктів обладнання в чисті приміщення дозволяється тільки через повітряні шлюзи. В чистих зонах необхідно підгримувати належну чистоту, що регламентується вимогами GMP, а повітря, що до них подається, повинно проходити очищення через фільтри відповідної ефективності. Допоміжні операції (підготовка вихідної сировини і матеріалів, виготовлення напівпродуктів, фасування в первинну упаковку, стерилізація) необхідно проводити в окремих зонах чистого приміщення. Необхідну ступінь чистоти повітря необхідно забезпечувати, базуючись на результатах валідації [19, 20].

\section{VII. ВИСНОВОК}

Хоча біобезпека та біозахист направлені на здійснення різних цілей, вони часто вирішуються разом, особливо в умовах обмеженого використання. Практика оцінки ризиків та управління ними закладена в широкій та надійній системі міжнародних, регіональних та національних нормативних актів та вказівок, що стосуються поводження, зберігання, заходів утримання, поводження 3 відходами, транспортування, пакування та маркування біологічних організмів, що перебувають у закритому режимі, включаючи ГМО, забезпечуючи тим самим захист здоров'я людей, тварин та рослин, а також навколишнього середовища.

Заходи 3 біобезпеки, призначені для забезпечення безпеки працівників лабораторій, включають використання різних первинних та вторинних бар'єрів, багато 3 яких зумовлені появою нових технологій у галузі матеріалознавства та техніки. Для мікробіологічних та біомедичних лабораторій було розроблено кілька рівнів біобезпеки, що забезпечують підвищення рівня персоналу та захисту навколишнього середовища.

Робота виконана в рамках гранту Національного фонду досліджень України 2020.01/0464 "Розробка концепції підготовки фахівців та підвищення кваліфікації 3 біобезпеки та біозахисту”.

\section{VIII. ПЕРЕЛІК ПОСИЛАНЬ}

[1] Bakanidze L., Imnadze P., Perkins D. Biosafety and biosecurity as essential pillars of international health security and cross-cutting elements of biological nonproliferation // BMC Public Health. 2010. Vol. 10, № Suppl 1. P. S12.

[2] WORLD HEALTH ORGANIZATION et al. Additional laboratory hazards-Noise. Laboratory biosafety manual. 3rd ed. 2004. P. 111.

[3] Sture J., Whitby S., Perkins D. Biosafety, biosecurity and internationally mandated regulatory regimes: compliance mechanisms for education and global health security // Med. Confl. Surviv. 2013. Vol. 29, № 4. P. 289-321.

[4] Zaki A.N. Biosafety and biosecurity measures: management of biosafety level 3 facilities // Int. J. Antimicrob. Agents. 2010. Vol. 36. P. S70-S74.

[5] Peng H., Bilal M., Iqbal H. Improved Biosafety and Biosecurity Measures and/or Strategies to Tackle LaboratoryAcquired Infections and Related Risks // Int. J. Environ. Res. Public Health. 2018. Vol. 15, № 12. P. 2697.

[6] Wurtz N. et al. Survey of laboratory-acquired infections around the world in biosafety level 3 and 4 laboratories // Eur. J. Clin. Microbiol. Infect. Dis. 2016. Vol. 35, № 8. P. 1247-1258.

[7] Pike R.M. Laboratory-associated infections: summary and analysis of 3921 cases. // Health Lab. Sci. 1976. Vol. 13, № 2. P. $105-$ 114.

[8] Phillips G.B., Runkle R.S. Laboratory design for microbiological safety. // Appl. Microbiol. 1967. Vol. 15, № 2. P. 378-389.

[9] Singh K. Laboratory-Acquired Infections // Clin. Infect. Dis. 2009. Vol. 49, № 1. P. 142-147.

[10] Sewell D.L. Laboratory-associated infections and biosafety. // Clin. Microbiol. Rev. 1995. Vol. 8, № 3. P. 389-405.

[11] Coelho A.C., García Díez J. Biological Risks and Laboratory-Acquired Infections: A Reality That Cannot be Ignored in Health Biotechnology // Front. Bioeng. Biotechnol. 2015. Vol. 3.

[12] Nisii C. et al. Biosafety Level-4 Laboratories in Europe: Opportunities for Public Health, Diagnostics, and Research // PLoS Pathog. / ed. Rall G.F. 2013. Vol. 9, № 1. P. e1003105.

[13] Kimman T.G., Smit E., Klein M.R. Evidence-Based Biosafety: a Review of the Principles and Effectiveness of Microbiological Containment Measures // Clin. Microbiol. Rev. 2008. Vol. 21, № 3. P. 403-425.

[14] Burnett L.C., Lunn G., Coico R. Biosafety: Guidelines for Working with Pathogenic and Infectious Microorganisms // Curr. Protoc. Microbiol. 2009. Vol. 13, № 1.

[15] Ta L., Gosa L., Nathanson D.A. Biosafety and Biohazards: Understanding Biosafety Levels and Meeting Safety Requirements of a Biobank. 2019. P. 213-225.

[16] Про забезпечення санітарного та епідемічного благополуччя населення: Закон України від 24.02.1994

[17] Про державну систему біобезпеки при створенні, випробуванні, транспортуванні та використанні генетично модифікованих організмів: Закон України від 31.05.2007

[18] Організація роботи лабораторій при дослідженні матеріалу, що містить біологічні патогенні агенти I-IV груп патогенності молекулярногенетичними методами: ДСНП від 21.08.2008

[19] Настанова. Лікарські засоби. Належна виробнича практика. СТ-Н МОЗУ 42-4.0:2015” від 14 грудня 2001 р. № 506 [20] Guidelines of 5 November 2013 on Good Distribution Practice of medicinal products for human use (Text with EEA relevance) (2013/C 343/01) 


\title{
БИОБЕЗОПАСНОСТЬ И ОХРАНА ТРУДА
}

\author{
Циник М.И., студентка \\ marytsinyk@gmail.com \\ Бесараб О. Б., к.т.н. \\ besarab@lll.kpi.ua \\ Мотроненко В. В. д-р філос. \\ motronenkovalya@gmail.com \\ Национальный технический университет Украины \\ “Киевский политехнический институт имени Игоря Сикорского" \\ г. Киев, Украина
}

\begin{abstract}
Реферат - Bопросы биологической безопасности и биозащить имеют важное значение для репутащии и ответственности каждого научного учреждения, будь то исследовательское, научное или производственное. Каждый риск - каким бы мальм он ни был - должен быть учтен, оченен и должным образом смягчен. В этой статье мы проводим обзор основных патогенных биологических объектов, предоставляем статистику соотношения выявленных случаев заболевания и смертности среди основных лабораторно-приобретенных инфекций (Laboratoryacquired infections) (LAI) и соотношение выявленных случаев заболевания и смертности среди основньх условнопатогенных биологических агентов. Рассматриваем подбор мероприятий, управляюших внедрением биобезопасности и биозащиты в ограниченных средах, и то, как они применяются в Украине, среди чего определяем, какие мероприятия проводятся в лаборатории каждого уровня биологической безопасности BSL. Коротко характеризуем особенности контроля за микробиологическим загрязнением биотехнологической и фармацевтической продукции. В результате проведенного анализа можно сделать вывод, что хотя биобезопасность и биозащита направлень на осуществление различных целей, они часто решаются вместе, особенно в условиях ограниченного использования. Предназначены для обеспечения безопасности работников лабораторий, включают использование различных первичных и вторичных барьеров, многие из которых обусловлены появлением новых технологий в области материаловедения и техники.
\end{abstract} Ключевые слова: биозащита, биобезопасность, охрана труда, группа риска, LAI, BSL.

\section{UDC 608.3:331.45](045)}

\section{BIOSAFETY AND WORK SAFETY}

\author{
Tsinyk M.I., student \\ marytsinyk@gmail.com \\ Besarab O.B. Candidate of Engineering Sciences \\ besarab@lll.kpi.ua \\ Motronenko V.V., Doctor of Philosophical Sciences \\ motronenkovalya@gmail.com \\ National Technical University of Ukraine \\ "Igor Sikorsky Kyiv Polytechnic Institute" \\ Kyiv, Ukraine
}

\begin{abstract}
Biosafety and biosecurity issues are important to the reputation and responsibility of every institution, whether it is research, scientific or industrial. Every risk, no matter how small, must be considered, assessed, and mitigated properly. In this article, we review the main pathogenic biological objects, provide statistics on the ratio of detected cases of disease and mortality among the main laboratory-acquired infections (LAI) and the ratio of detected cases of disease and mortality among the main opportunistic biological agents. We consider the selection of measures that manage the implementation of biosafety and biosecurity in limited environments, and how they are applied in Ukraine, among which we determine what measures are carried out in the laboratory of each biological safety levels BSL level. Briefly describe the features of control over microbiological contamination of biotechnological and pharmaceutical products. As a result of the analysis, we could conclude that although biosafety and biosecurity are aimed at achieving different goals, they are often used together, especially in conditions of limited use. Designed to ensure the safety of laboratory staff, including the use of various primary and secondary barriers, many of which are due to the emergence of new technologies in the field of materials science and technology.
\end{abstract}

Key words: biosecurity, biosafety, labor protection, risk group, LAI, BSL 